\title{
Regenerative Heat Treatment of Low Alloy Cast Steel
}

Grzegorz Golański

Additional information is available at the end of the chapter

http://dx.doi.org/10.5772/50505

\section{Introduction}

Cylinder and valve chamber castings of large power steam turbines are usually made of low alloy $\mathrm{Cr}-\mathrm{Mo}-\mathrm{V}$ and $\mathrm{Cr}$ - Mo cast steels. Forming of the microstructure and mechanical properties of cast steels takes place through heat treatment, thus far mostly consisting of normalizing and tempering. As a result of such a treatment the cast steels of diverse wall thickness reveal microstructures from ferritic - pearlitic to bainitic - ferritic with various ferrite, pearlite and bainite amount.

Operation of the cast steels under creep conditions contributes to the occurrence of deformations, fractures and changes in the microstructure, decreasing their functional properties. The resistance to crack expressed by impact energy falls drastically. The value of impact energy of test pieces taken from cast steels after long-term service was considerably below the required level of 27J, frequently reaching the value of 6 - 10J (Fig. 1).

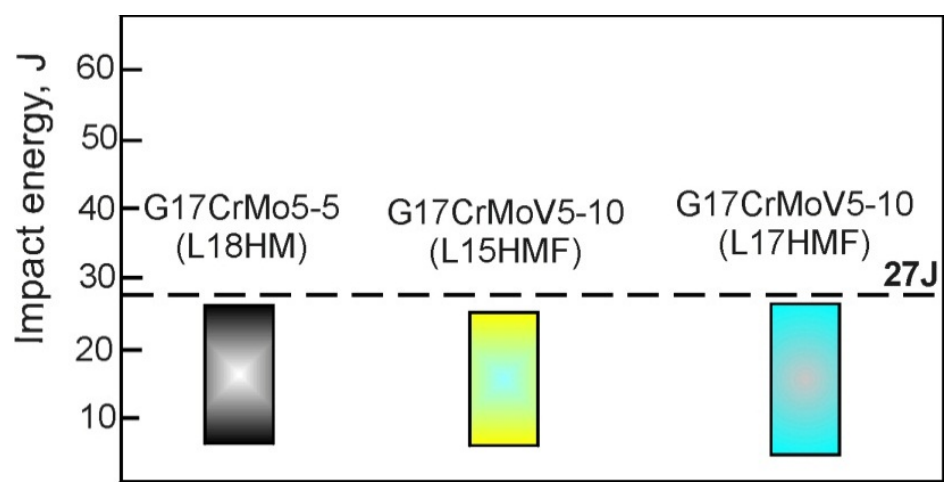

Figure 1. Impact energy of turbine cylinder cast steel in the post-operating condition 
Along with the fall of impact energy there is also a growth of nil ductility transition (NDT) temperature, frequently rising above $50 \div 60{ }^{\circ} \mathrm{C}$. Large decrease in crack resistance is usually accompanied by a slight decrease in the strength properties (Fig. 2).

Unfavourable changes in mechanical properties of the castings are related to the changes in microstructure which occur during long term service at elevated temperatures, first and foremost to:

- the preferential precipitation of carbides on grain boundaries, as well as changes in morphology and dispersion of precipitates;

- segregation of phosphorus and other trace elements to grain boundaries and near boundary areas; disintegration of pearlite or/and bainite areas.

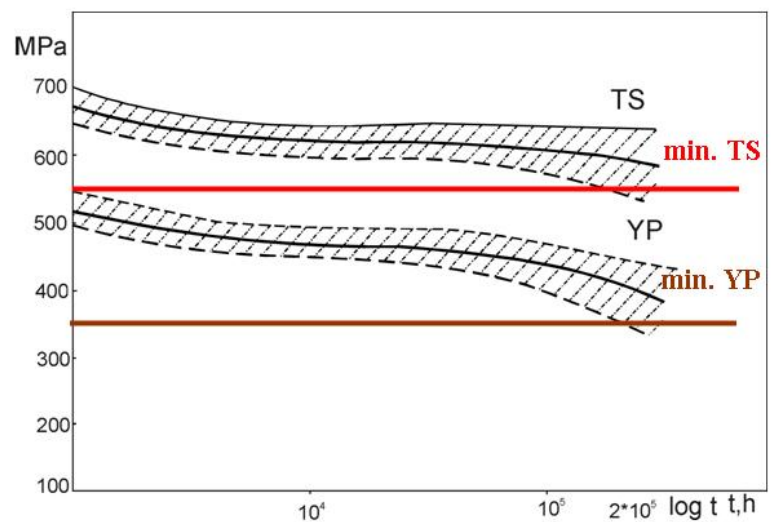

Figure 2. Changes in tensile strength (TS) and yield strength (YS) depending on the time of service

Lowering of impact energy as a result of long-term service depends largely on the as received microstructure of a cast steel. The impact energy decrease is the smallest in the case of tempered bainite microstructure or bainitic - ferritic microstructure, with ferrite amount not higher than 5\% (Fig. 3). High impact energy of quenched and tempered cast steel, considerably higher than 100J, guarantees that during long-term service of steel castings with low phosphorus volume fraction $(\leq 0.015 \% \mathrm{P})$, the impact energy will not fall below the minimum required value of $27 \mathrm{~J}$.

Similar tendency has been noticed in new low-alloy bainitic 7CrWVMoNb9 - 6 (P23) steel. Impact energy in the case of this cast steel, whose microstructure is of tempered bainite in the as-received condition, after around 10 years of operation at the temperature of $555{ }^{\circ} \mathrm{C}$ and pressure 4.2MPa, was on the level of $70-80 \mathrm{~J} / \mathrm{cm}^{2}$.

Degradation of the microstructure of castings and the related gradual decreasing of mechanical properties, however, do not limit the possibility of their further operation, especially as in most of the examined castings there were no irreversible creep changes observed. One of the conditions for extending the time of safe operation for cast steels above the calculated service time is running the process of revitalization of the castings. 


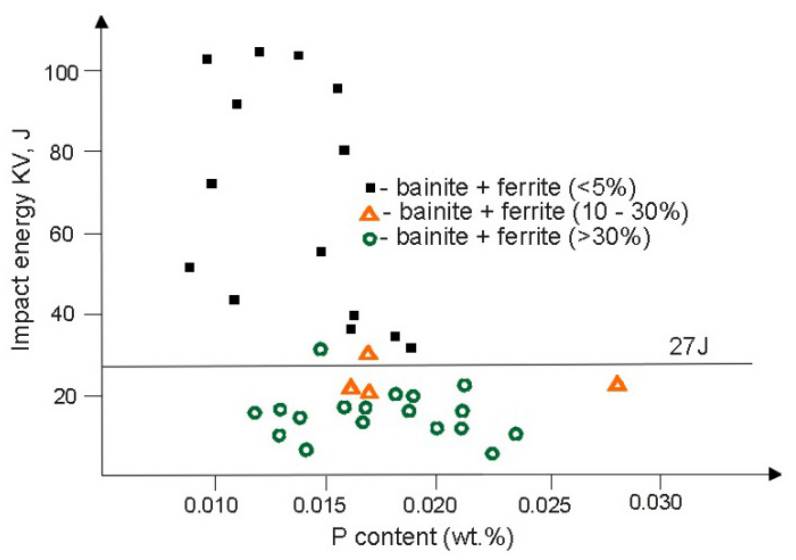

Figure 3. Influence of phosphorus amount and microstructure on impact energy $\mathrm{KV}$ of the $\mathrm{Cr}-\mathrm{Mo}-\mathrm{V}$ cast steel after long-term operation at the temperature of $535{ }^{\circ} \mathrm{C}$

The revitalization process consists in heat treatment of turbine cylinders in order to regenerate the structure to the extent which allows the improvement of plastic properties (increase in impact energy, decrease in the nil ductility transition temperature). Regenerative heat treatment of castings applied in industry so far consists in normalizing/full annealing from the austenitizing temperature with the following high-temperature tempering/under annealing. The ferritic - pearlitic or ferritic - bainitic structure, obtained as a result of the above-mentioned heat treatment, provides the required impact energy of $\mathrm{KV}>27 \mathrm{~J}$, however, with the strength properties being comparable to those after operation.

Modern hardening plants applying aqueous solutions of polymers as a cooling agent make the cooling of massive castings possible at programmed rate which provides an optimum structure throughout the whole casting section.

Regenerative heat treatment at costs not exceeding $40 \%$ of a new casting's price, allows obtaining functional properties (yield strength, impact energy, NDT temperature) comparable to the properties of new castings. Regenerated cylinder is fit for further operation at least for another 100000 hours.

In order to achieve an improvement in mechanical properties of cast steels after long-term operation, the following changes in the degraded microstructure are necessary:

- grain refinement - leads to an increase in crack resistance, decreases the NDT temperature and raises yield strength;

- eliminating irreversible brittleness caused by phosphorus segregation to grain boundaries and interphase boundary: matrix/carbides;

- $\quad$ removal of the needle shaped ferrite (Widmannstätten's ferrite);

- removal of pearlite precipitated on ferrite grain boundaries;

- dissolving of carbides in austenite, especially the carbides precipitated on grain boundaries, in order to obtain the required strength properties in the regenerated microstructure (hardness and tensile strength). 
The research aim: The aim of the performed research was to determine the influence of regenerative heat treatment on the microstructure and properties of $\mathrm{Cr}-\mathrm{Mo}-\mathrm{V}$ cast steel with its microstructure degraded by long-term service and mechanical properties being lower than the minimum ones expected in the new castings.

\section{Material for research}

The material for study was $\mathrm{Cr}-\mathrm{Mo}-\mathrm{V}$ low-alloy L21HMF cast steel (designation according to Polish Standards) with its chemical composition given in Table 1. Test pieces for investigation were taken from an inner cylinder of a steam turbine serviced for around 186000 hours at the temperature of $540{ }^{\circ} \mathrm{C}$ and pressure of $13.5 \mathrm{MPa}$.

\begin{tabular}{|c|c|c|c|c|c|c|c|}
\hline \hline C & Mn & Si & P & S & Cr & Mo & V \\
\hline \hline 0.19 & 0.74 & 0.30 & 0.017 & 0.014 & 1.05 & 0.56 & 0.28 \\
\hline
\end{tabular}

Table 1. Chemical composition of the L21HMF cast steel, \% mass.

\subsection{Microstructure and properties of the examined cast steel after service}

In the post-operating condition the L21HMF cast steel was characterized by a degraded ferritic-pearlitic microstructure (Fig. 4). The dominant phase in the microstructure after operation was quasi-polygonal ferrite. The size of ferrite grain in the cast steel was diverse and ranged from 88.4 to $31.2 \mu \mathrm{m}$, which corresponds to the grain size grade: $4 \div 7$, according to ASTM standard scale.
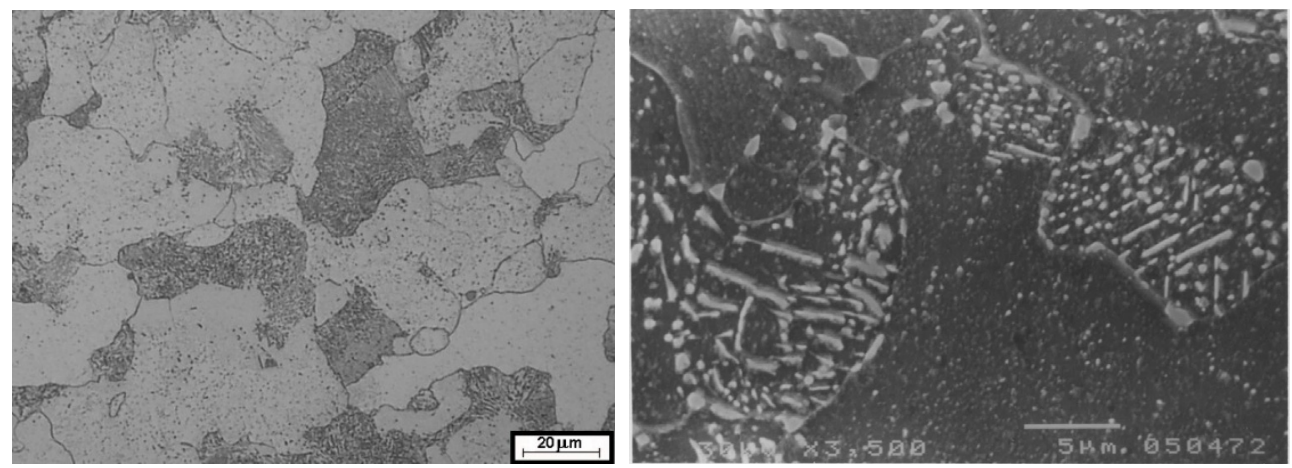

Figure 4. The microstructure of L21HMF cast steel after service

Long-term service of $\mathrm{Cr}-\mathrm{Mo}-\mathrm{V}$ cast steel contributed to the changes in microstructure, including:

- $\quad$ preferential carbide precipitation of $\mathrm{M}_{23} \mathrm{C}_{6}$ carbides on ferrite grain boundaries. In some areas the number of carbides precipitated on boundaries was so large that they formed the so-called "continuous grid" of precipitates; 
- the process of degradation of pearlite grains consisting in fragmentation, spheroidization and coagulation of pearlitic carbides. Performed identifications have revealed the occurrence of the $\mathrm{M}_{3} \mathrm{C}$ and $\mathrm{M}_{7} \mathrm{C}_{3}$ type of precipitations in those areas (Fig. 5);
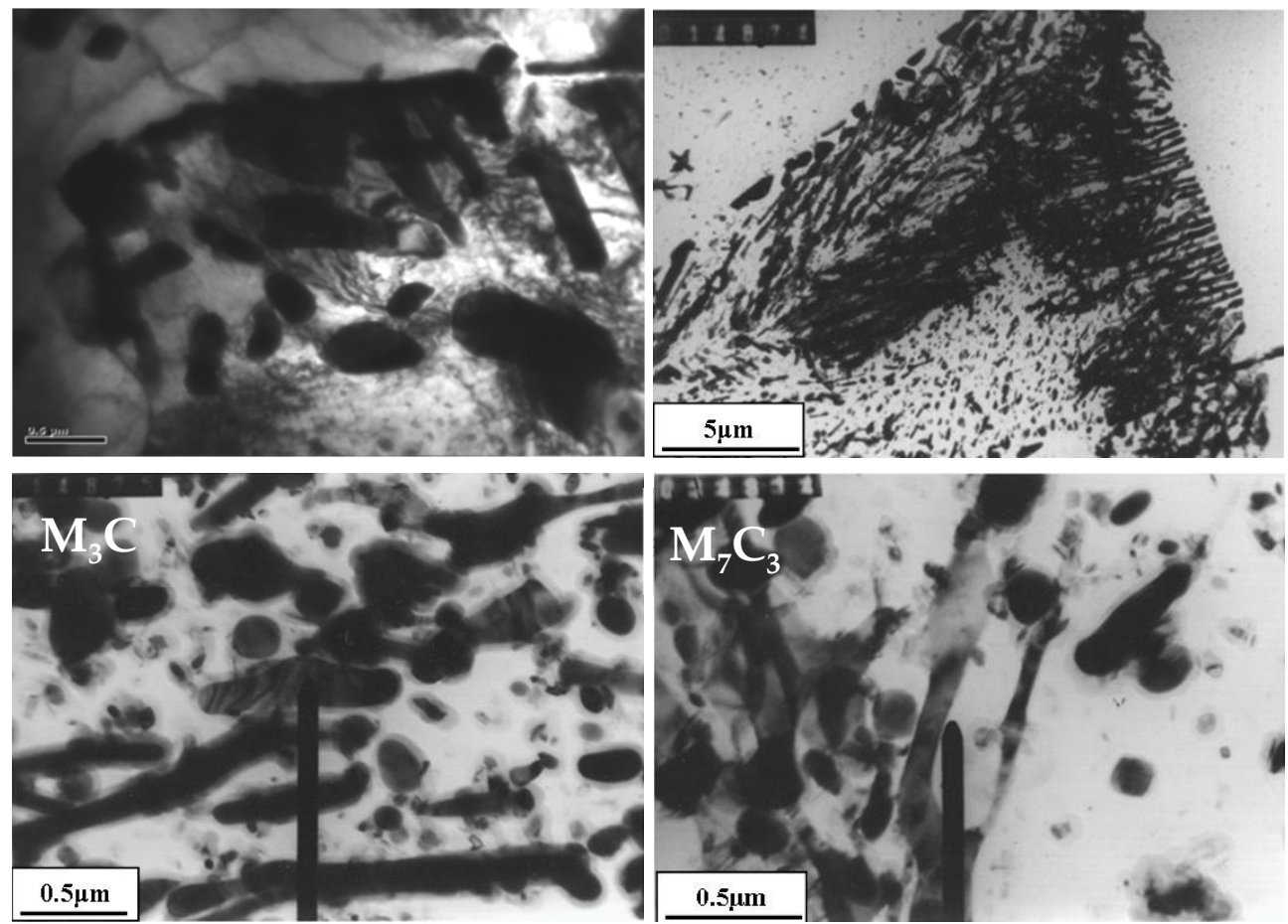

Figure 5. Morphology and type of carbides in pearlite grain

- precipitation of compound carbide complexes called „H - carbides”. The compound complexes of precipitates are created by $\mathrm{MC}$ and $\mathrm{M}_{2} \mathrm{C}$ carbides, where the $\mathrm{MC}$ carbide is a "horizontal" precipitation, while $\mathrm{M}_{2} \mathrm{C}$ carbides are precipitations of "vertical" type (Fig. 6). This sort of compound precipitations is defined as „H - carbide”. During longterm operation the MC carbide is enriched in molybdenum as a result of diffusion. The growth of molybdenum concentration in the interphase areas of $\mathrm{MC} /$ matrix makes it possible for the "needle-shaped" precipitations of $\mathrm{M}_{2} \mathrm{C}$ (rich in molybdenum) to nucleate on the interphase boundary: $\mathrm{MC}$ carbide/ferrite. These processes run more intensely in the border areas of grains, which results in the occurrence of precipitation free zones. The appearance of such zones may be the cause of slow reduction of the strength properties, the yield strength in particular, during long-term operation. The occurrence of this type of complexes results in a decay of fine-dispersion MC carbides which may lead to the fall of creep resistance in the serviced materials. A similar phenomenon can be seen at present in the new high-chromium cast steels for power industry, where the $\mathrm{Z}$ phase is being formed and developed at the expense of fine dispersion precipitates of the MX type, which causes a drastic drop of creep resistance of these cast steels. 

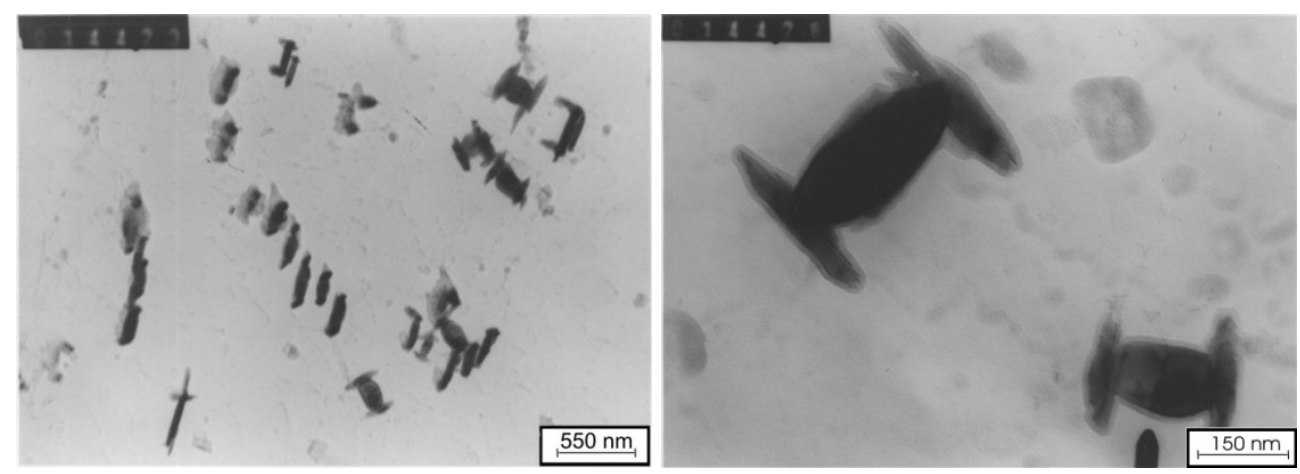

Figure 6. Precipitation of „ $\mathrm{H}$ - carbide” type in the cast steel

Mechanical properties of L21HMF cast steel after long-term service are shown in Table 2.

\begin{tabular}{|c|c|c|c|c|c|c|c|}
\hline Material & $\begin{array}{c}\text { TS } \\
\mathrm{MPa}\end{array}$ & $\begin{array}{c}\text { YS } \\
\mathrm{MPa}\end{array}$ & $\begin{array}{c}\text { El. } \\
\%\end{array}$ & $\begin{array}{c}\mathrm{KV} \\
\mathrm{J}\end{array}$ & $\mathrm{HV} 30$ & $\begin{array}{c}\text { DBTT } \\
{ }^{\circ} \mathrm{C}\end{array}$ & Microstructure \\
\hline L21HMF & 545 & 305 & 26 & 10 & 156 & 65 & ferritic-pearlitic \\
\hline $\begin{array}{c}\text { Requirements } \\
\text { of } \mathrm{PN}^{*}\end{array}$ & $\begin{array}{c}500 \\
\div\end{array}$ & $\begin{array}{c}\text { min. } \\
670\end{array}$ & min. 20 & min. 27 & $\begin{array}{c}140 \\
\div \\
197^{* *}\end{array}$ & - & - \\
\hline
\end{tabular}

*- PN - 89/ H - 83157, ** - hardness according to Brinell,

Table 2. Mechanical properties and microstructure of the L21HMF cast steels after service

Tensile strength and elongation of the examined cast steel after service were higher than the minimum values required for new castings, while the value of yield strength was lower than the minimum required by $15 \mathrm{MPa}$. Hardness of the investigated cast steel after operation amounted to $156 \mathrm{HV} 30$.

A significant feature of the material proving its strain capacity, apart from elongation determined in the static test of tension, is the value of impact energy. Knowledge of this factor gives the possibility of assuming the right temperature for the hydraulic pressure tests used in industrial practice, as well as the right conditions of start-ups and shut-downs of a boiler, adjusted to the material state after long-term service. After operation the examined cast steel was characterized by low impact energy amounting to $10 \mathrm{~J}$, and the cracking of samples occurred through the transcrystalline fissile mechanism (typical for brittle fractures) with little energy absorbed due to the limited plastic strain preceding the decohesion. Fissile cracking requires little energy supply which is necessary for crack propagation, hence the low impact energy of the cast steel after service (Fig. 7). Low impact energy of the examined materials is related to the nil ductility temperature (brittle temperature). The fracture appearance transition temperature determined for the examined cast steel amounted to 65 ${ }^{\circ} \mathrm{C}$. 

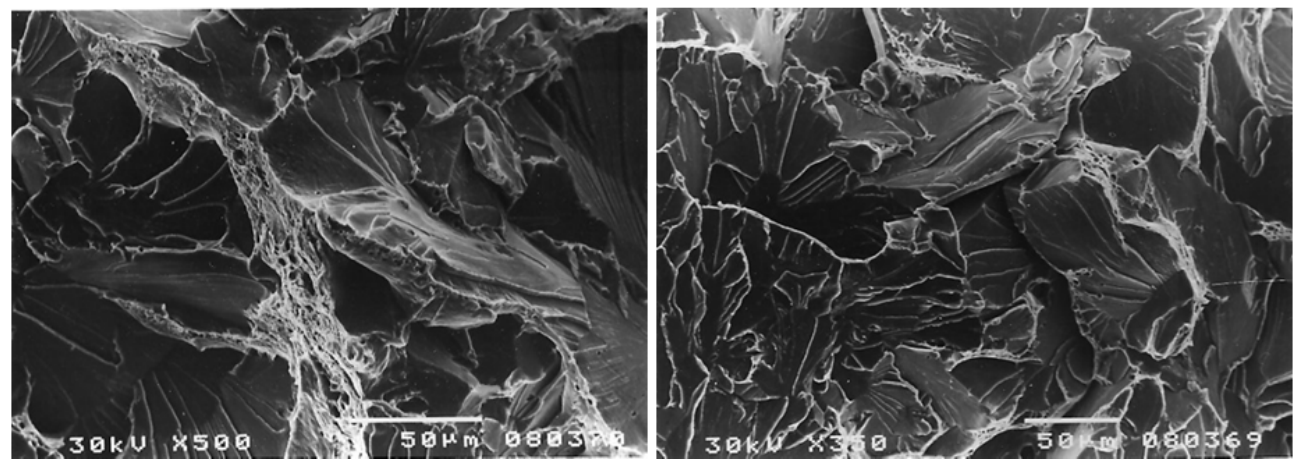

Figure 7. Transcrystalline ductile fracture with areas of microductility and secondary cracks

\subsection{Influence of austenitizing parameters on the size of prior austenite grain}

Influence of austenitization parameters on the prior austenite grain size has been described in a quantitative way using chosen stereological and statistical parameters, such as: mean diameter and mean area of grain, and also the coefficient of variation of grain size $v$ was calculated. The $v$ coefficient is characterized by the inhomogeneity of grain sizes: the more heterogeneous grains in terms of size within the casting, the higher the values of variation coefficient. The tests were run for the austenitizing temperature range of $-910 \div 970{ }^{\circ} \mathrm{C}$ with the "measurement step" $-15^{\circ} \mathrm{C}$ and times of holding at the austenitizing temperature: 3 and 5 hours.

The character of austenite grain distributions was determined using the $\lambda$ - Kolmogorov test of goodness of fit with normal distribution for logarithmed values (Fig. 8). The assumed significance level was $\alpha=0.01$, with its limiting statistics value amounting to 1.63. Selected logarithm-normal layouts of mean diameters and mean surface areas of former austenite grains for austenitization option of $925^{\circ} \mathrm{C}$ and holding time 3 hours, are shown in Fig. 8. Obtained results of the tests are presented in Table 3 and 4 and graphically shown in Fig. $9 \div 11$.

\begin{tabular}{||c|c|c|c|c|c|c|c|c||}
\hline $\begin{array}{c}\text { Heat } \\
\text { treatment } \\
\text { parameters, } \\
\mathbf{o}_{\mathbf{C} / \mathbf{h}}\end{array}$ & $\begin{array}{c}\text { Amount } \\
\mathbf{n}\end{array}$ & $\begin{array}{c}\text { Min. } \\
\text { diameter } \\
\text { of grain, } \\
\boldsymbol{\mu} \mathbf{m}\end{array}$ & $\begin{array}{c}\text { Max. } \\
\text { diameter } \\
\text { of grain, } \\
\boldsymbol{\mu m}\end{array}$ & $\begin{array}{c}\text { Diameter } \\
\text { of grain, } \\
\boldsymbol{\mu m}\end{array}$ & $\begin{array}{c}\text { Standard } \\
\text { deviation }\end{array}$ & $\lambda_{\text {emp }}$ & $\lambda_{\alpha}=\mathbf{0 . 0 1}$ & $\frac{\lambda_{\text {emp }}}{\lambda_{\alpha}=\mathbf{0 . 0 1}}$ \\
\hline \hline $910 / 3$ & 976 & 2 & 29 & 11.34 & 6.36 & 1.54 & 1.63 & 0.945 \\
\hline $925 / 3$ & 969 & 2 & 30 & 9.84 & 5.34 & 1.36 & 1.63 & 0.834 \\
\hline $940 / 3$ & 954 & 2 & 31 & 10.16 & 6.22 & 1.56 & 1.63 & 0.957 \\
\hline $955 / 3$ & 964 & 2 & 38 & 14.08 & 9.34 & 1.36 & 1.63 & 0.834 \\
\hline $970 / 3$ & 2024 & 2 & 297 & 22.14 & 17.73 & 2.26 & 1.63 & 1.387 \\
\hline $910 / 5$ & 946 & 2 & 27 & 9.36 & 5.70 & 1.35 & 1.63 & 0.828 \\
\hline $925 / 5$ & 915 & 2 & 28 & 11.00 & 7.01 & 1.55 & 1.63 & 0.951 \\
\hline $940 / 5$ & 959 & 2 & 32 & 9.05 & 5.41 & 1.33 & 1.63 & 0.816 \\
\hline $955 / 5$ & 937 & 2 & 39 & 12.02 & 8.37 & 1.18 & 1.63 & 0.724 \\
\hline $970 / 5$ & 2034 & 2 & 324 & 23.67 & 18.31 & 1.43 & 1.63 & 0.877 \\
\hline
\end{tabular}

Table 3. The results of measurements and calculations of the size of prior austenite grains for the cast steel 


\begin{tabular}{||c|c|c|c|c|c|c|c|c||}
\hline $\begin{array}{c}\text { Heat } \\
\text { treatment } \\
\text { parameters, } \\
{ }^{\mathbf{C}} \mathbf{C} / \mathbf{h}\end{array}$ & $\begin{array}{c}\text { Amount } \\
\mathbf{n}\end{array}$ & $\begin{array}{c}\text { Min. area } \\
\text { of grain, } \\
\boldsymbol{\mu m}^{2}\end{array}$ & $\begin{array}{c}\text { Max. area } \\
\text { of grain, } \\
\boldsymbol{\mu m}^{\mathbf{2}}\end{array}$ & $\begin{array}{c}\text { Mean area } \\
\text { of grain, } \\
\boldsymbol{\mu m}^{2}\end{array}$ & $\begin{array}{c}\text { Standard } \\
\text { deviation }\end{array}$ & $\lambda_{\text {emp }}$ & $\lambda_{\alpha}=\mathbf{0 . 0 1}$ & $\frac{\lambda_{\text {emp }}}{\lambda_{\alpha}=\mathbf{0 . 0 1}}$ \\
\hline \hline $910 / 3$ & 976 & 4 & 695 & 142.67 & 204.58 & 1.74 & 1.63 & 1.067 \\
\hline $925 / 3$ & 969 & 3 & 741 & 104.27 & 173.60 & 1.27 & 1.63 & 0.779 \\
\hline $940 / 3$ & 954 & 3 & 810 & 121.34 & 172.77 & 1.40 & 1.63 & 0.859 \\
\hline $955 / 3$ & 964 & 3 & 1302 & 187.41 & 379.31 & 1.59 & 1.63 & 0.975 \\
\hline $970 / 3$ & 2024 & 3 & 95722 & 812.62 & 2138.56 & 1.99 & 1.63 & 1.221 \\
\hline $910 / 5$ & 946 & 3 & 608 & 101.07 & 162.93 & 1.07 & 1.63 & 0.656 \\
\hline $925 / 5$ & 915 & 2 & 741 & 144.72 & 248.95 & 1.61 & 1.63 & 0.988 \\
\hline $940 / 5$ & 959 & 3 & 842 & 94.03 & 147.10 & 1.00 & 1.63 & 0.613 \\
\hline $955 / 5$ & 937 & 2 & 1533 & 391.66 & 423.09 & 0.98 & 1.63 & 0.601 \\
\hline $970 / 5$ & 2034 & 3 & 102305 & 915.33 & 2408.43 & 1.53 & 1.63 & 0.939 \\
\hline
\end{tabular}

Table 4. The results of measurements and calculations of the size of prior austenite grains for the cast steel
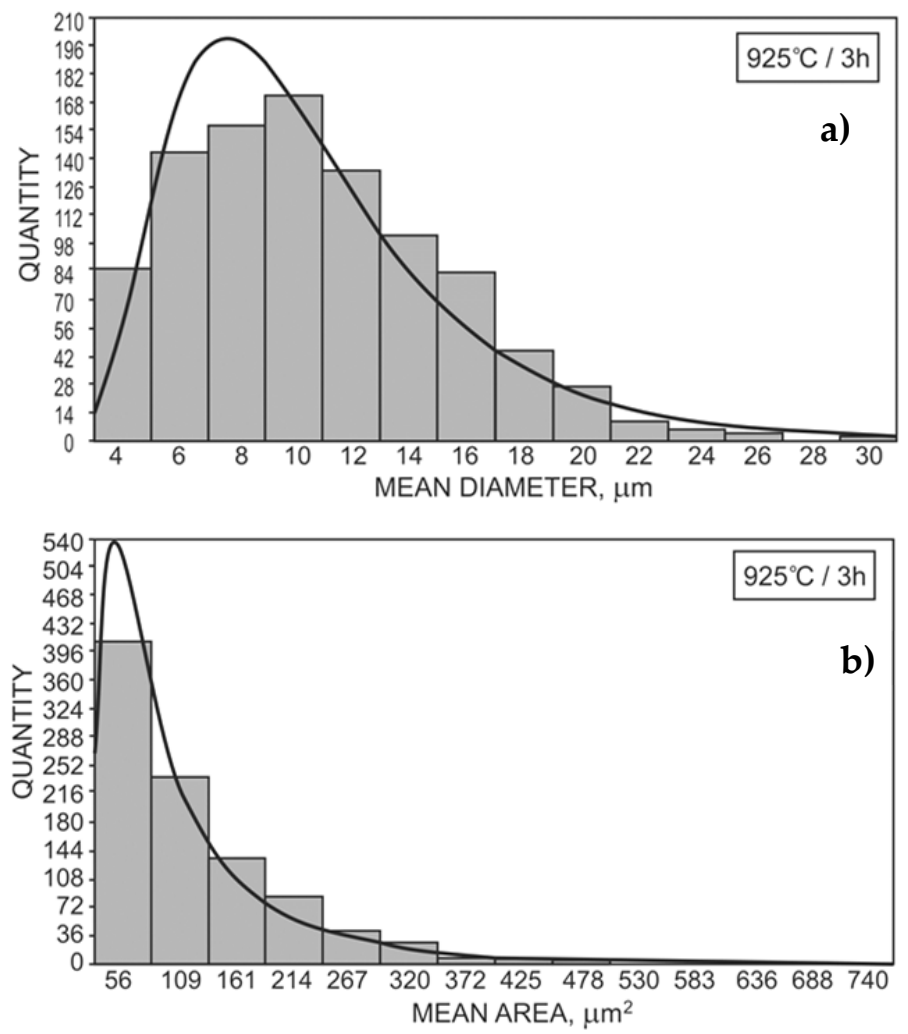

Figure 8. Logarithm - normal layout of grains for : a) mean diameter; b) mean surface area 

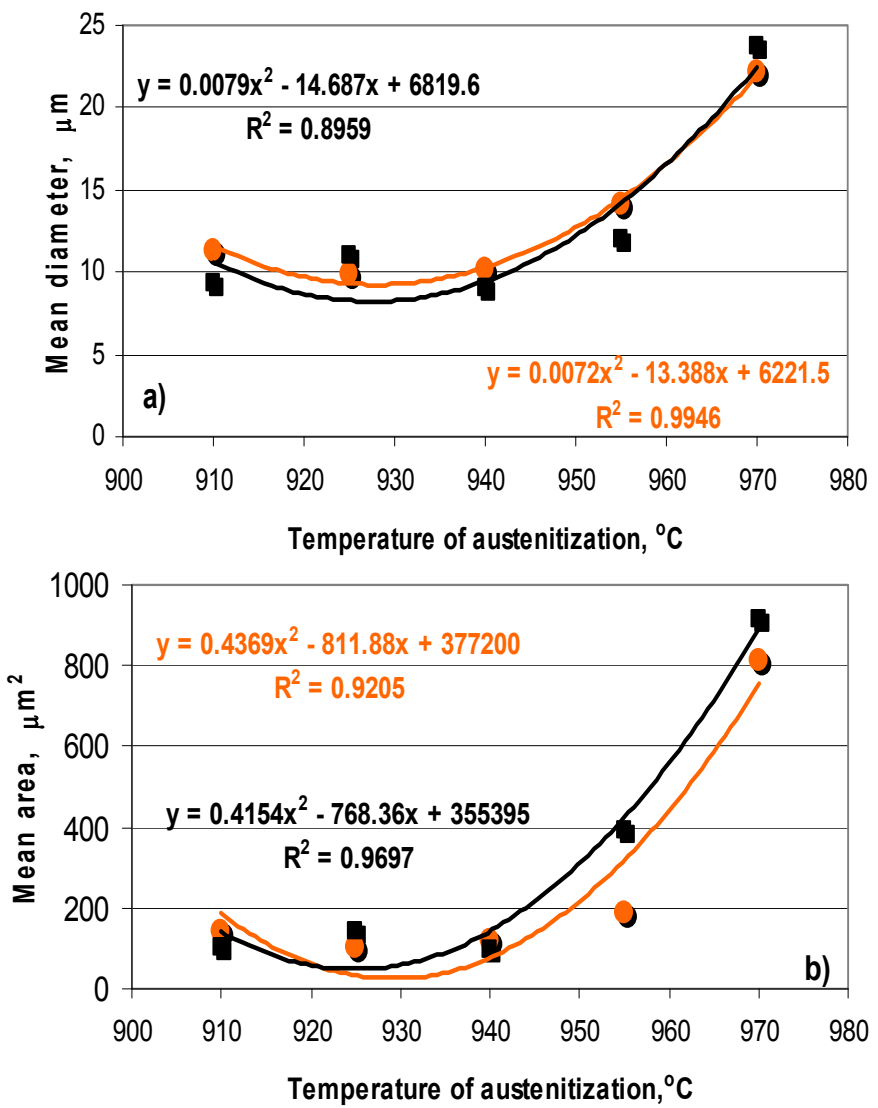

Figure 9. Influence of austenitization temperature on: a) mean grain diameter; b) mean surface area depending on the time of holding (3hrs - orange, 5hrs - black) of L21HMF cast steel

The mean diameters of grains and their mean areas change continuously and reveal lognormal layouts on the significance level of $\alpha=0.01$ ( $\left.\lambda_{\text {emp. }} / \lambda_{0.01}<1\right)$. The exceptions were the treatment variants as follows: austenitization temperature of $910{ }^{\circ} \mathrm{C}$ and time $-3 \mathrm{~h}$ for the mean area (fulfilled for lower significance level of $\alpha=0.001$ ) and the temperature of $970{ }^{\circ} \mathrm{C}$ and time - $3 \mathrm{~h}$ for both: mean diameter and mean area of prior austenite grain. Within the range of austenitization temperatures: $910 \div 940{ }^{\circ} \mathrm{C}$ for holding times: 3 and $5 \mathrm{hrs}$, the mean diameters and areas of prior austenite grain do not reveal any considerable differences. (Fig. 9). The values of the mean diameters and areas for this range of austenitization amounted to: $9.05 \div 11.34 \mu \mathrm{m}$ and $94.03 \div 144.72 \mu \mathrm{m}^{2}$, respectively. The above-mentioned measurements can be confirmed by the calculated values of $v$ coefficient, specifying heterogeneity in terms of grain sizes, which are the lowest for this range of austenitizing temperatures (Fig. 10), and by the distributions of frequency of cumulated grains (Fig. 11). 

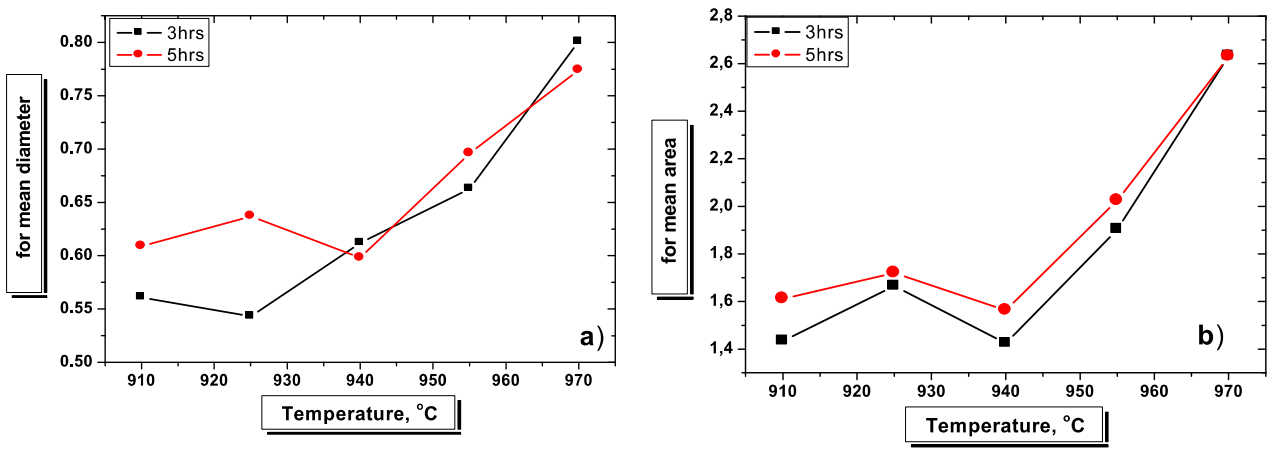

Figure 10. Interrelation between the heterogeneity factor $(v)$ of former austenite grain size in the cast steel and the austenitizing parameters for: a) mean diameter; b) mean grain area
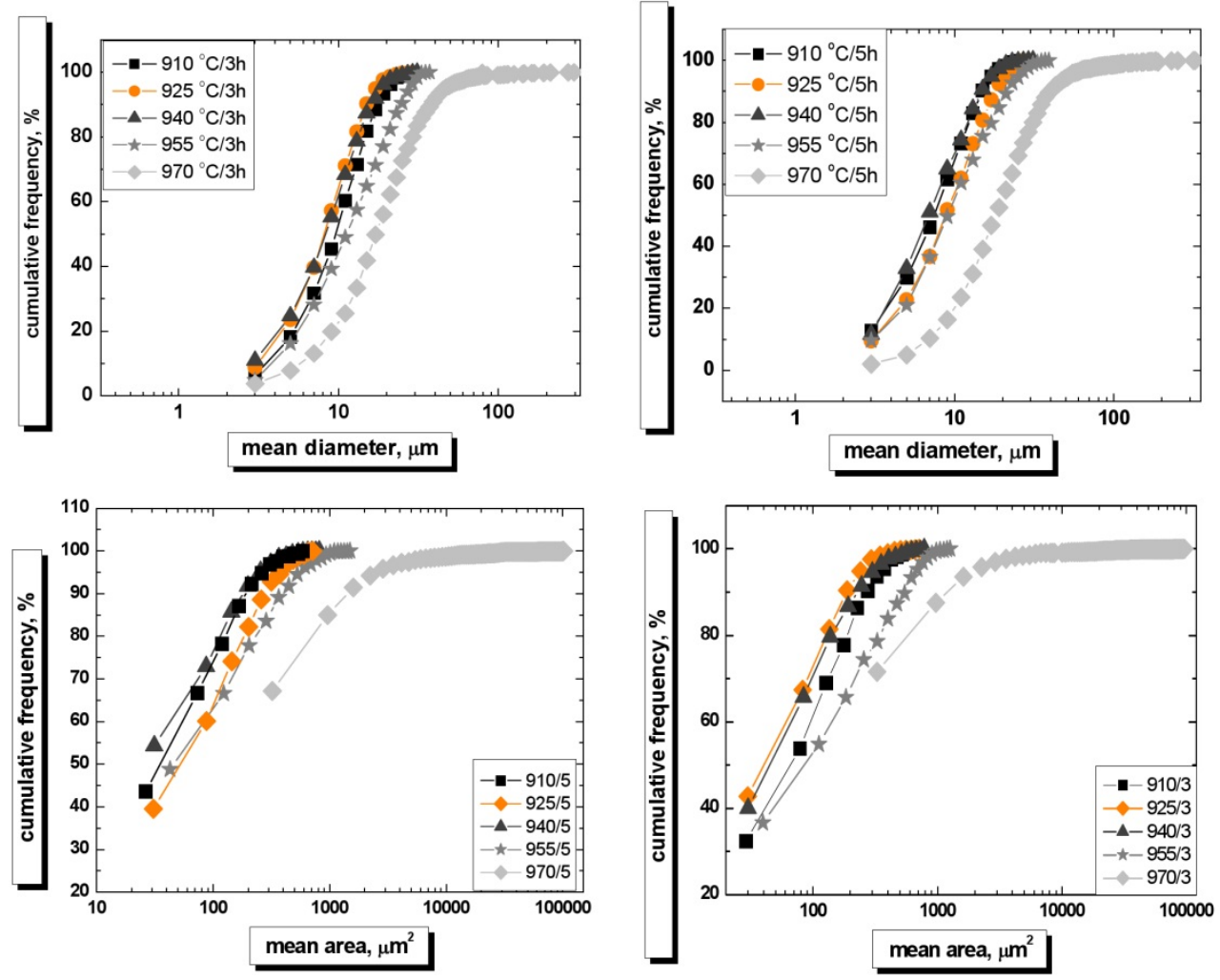

Figure 11. Distributions of frequency of cumulated grains 
At the temperature of $970{ }^{\circ} \mathrm{C}$ the grain growth was observed - mean diameter increased over two times, while the mean area about five times in comparison with the temperature range of $910 \div 940{ }^{\circ} \mathrm{C}$.

\subsection{Determining the influence of cooling rate on the microstructure and properties}

In order to determine the influence of cooling rates, allowing proper selection of parameters for the regenerative heat treatment, the TTT curves were plotted for L21HMF cast steel. On the basis of results achieved by means of dilatometric tests, a graph was drawn up, as shown in Fig 12. It illustrates the influence of cooling rate in the temperature range of $800 \div 500{ }^{\circ} \mathrm{C}$ on the structure and hardness of the investigated cast steel.

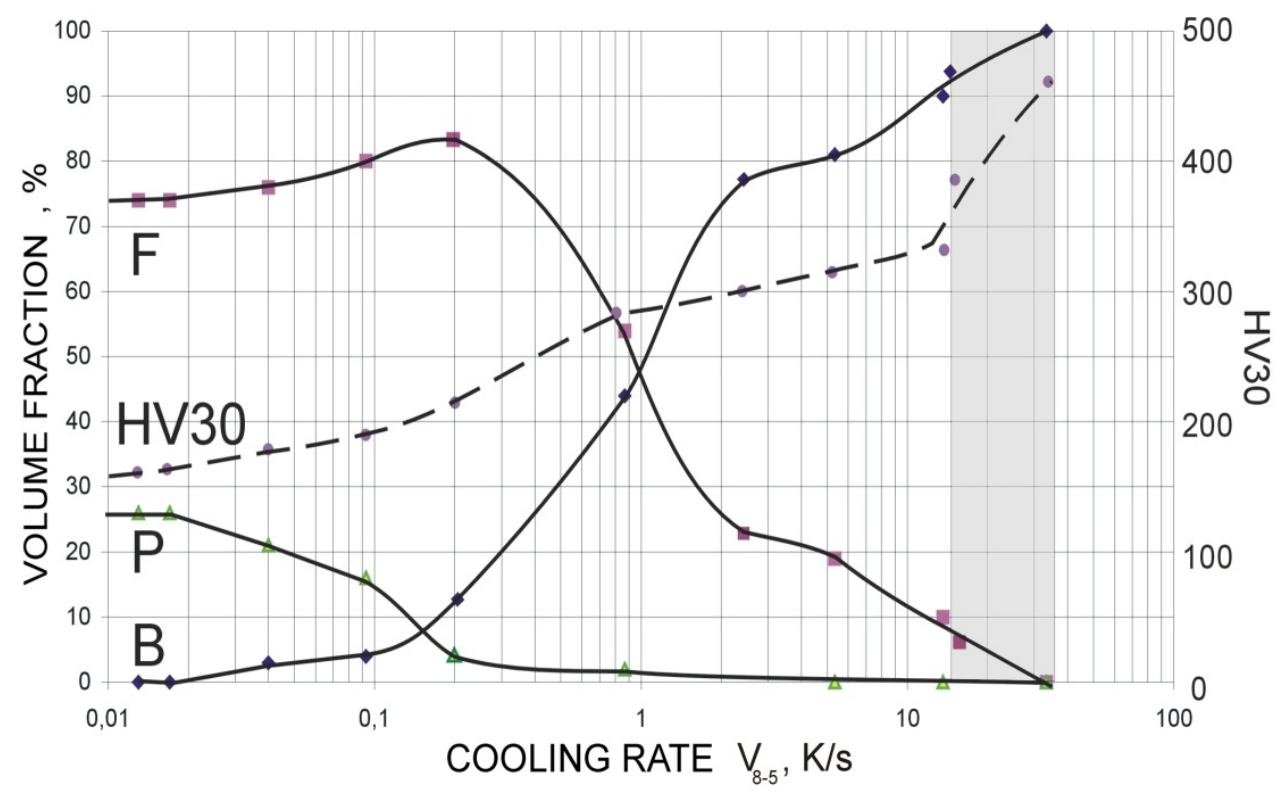

Figure 12. Influence of the cooling rate on structure and hardness of the cast steel

Analysis of the curves presented in Fig. 10 allows to state that in the case of L21HMF cast steel, whose chemical composition is given in Table 1 , austenite cooled at $0.004 \mathrm{~K} / \mathrm{s} \leq \mathrm{v} 8-5 \leq$ $0.017 \mathrm{~K} / \mathrm{s}$ gets transformed into ferrite and pearlite. The rate of cooling for austenite: $0.023<$ v8-5 $\leq 0.869 \mathrm{~K} / \mathrm{s}$ makes it possible to obtain ferritic - pearlitic - bainitic structures. Whereas after cooling of the cast steel at the range of $0.869 \mathrm{~K} / \mathrm{s}<\mathrm{v} 8-5 \leq 14.630 \mathrm{~K} / \mathrm{s}$ bainitic - ferritic structures were obtained, with an increasing bainite volume fraction as the cooling rate increased. Bainitic structure with around $6 \%$ volume fraction was received for the cooling rate of $\mathrm{v} 8-5 \geq 14.630 \mathrm{~K} / \mathrm{s}$. 


\subsection{Influence of heat treatment on the microstructure and properties of L21HMF cast steel}

The L21HMF cast steel was subject to heat treatment consisting in three-hour austenitizing of test pieces at the temperature of $910{ }^{\circ} \mathrm{C}$ and the following cooling at the rate corresponding to the processes of: bainitic hardening, normalizing and full annealing. The test pieces, bainite-hardened and normalized, were then tempered in the temperature range of $690 \div 730{ }^{\circ} \mathrm{C}$ and $690 \div 720{ }^{\circ} \mathrm{C}$, respectively. While the test pieces cooled slowly from the austenitizing temperature (fully annealed), were subject to $(\alpha+\gamma)$ annealing (under annealing) at the temperatures of $780 \div 860{ }^{\circ} \mathrm{C}$. Examples of microstructure of the examined cast steel after heat treatment are illustrated in Fig. 13.
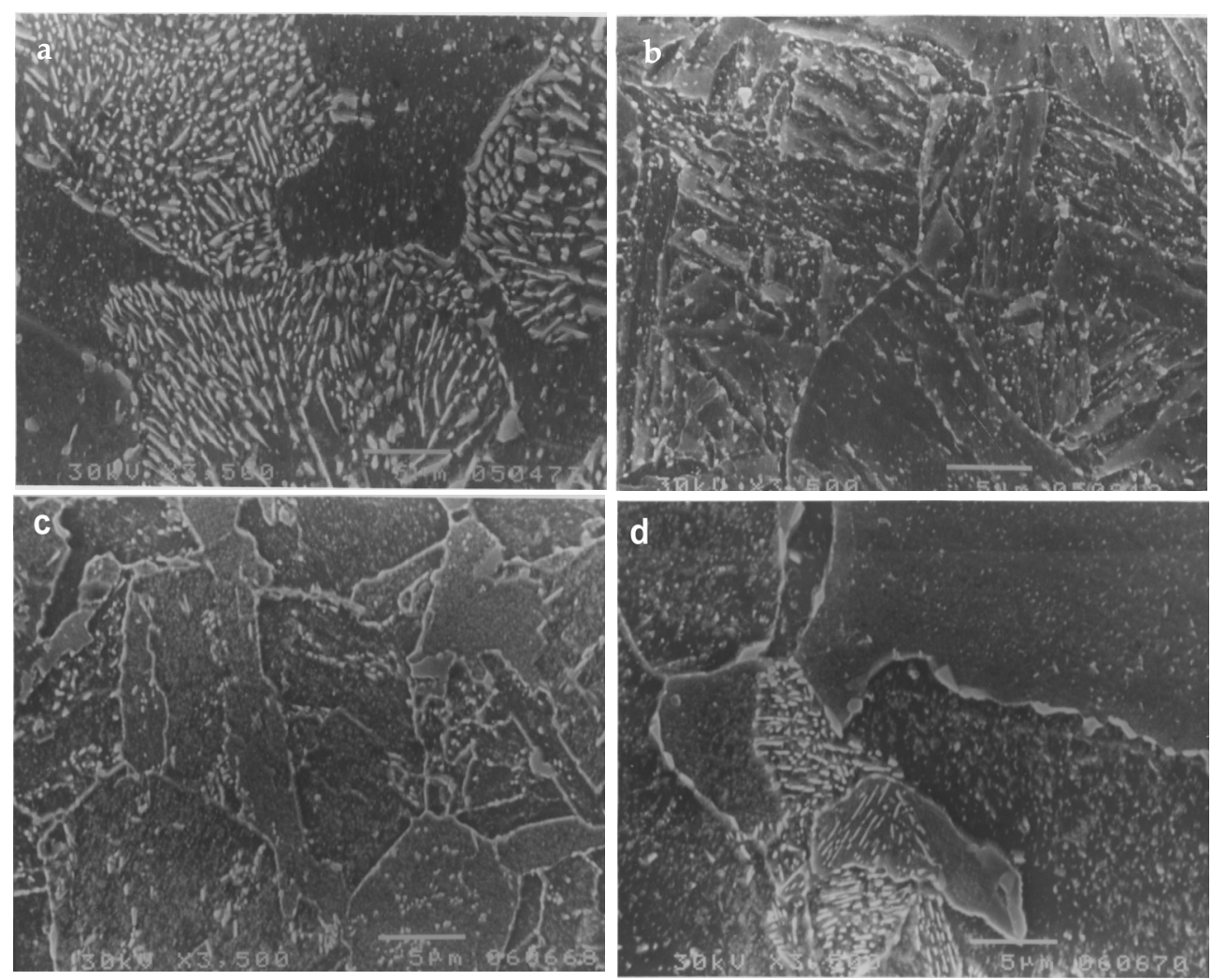

Figure 13. Microstructure of cast steel after: a) service; b) bainitic hardening and tempering; b) normalizing and tempering; c) full annealing and tempering

Bainitic hardening made it possible to obtain bainitic - ferritic microstructure in $\mathrm{Cr}-\mathrm{Mo}-\mathrm{V}$ cast steel. The amount of ferrite in the microstructure did not exceed $6 \%$. In the tempered microstructure there were numerous precipitations of carbides on the lath boundaries, as 
well as inside and on the boundaries of prior austenite grain. Matrix after heat treatment was characterized by high dislocation density, however, some sparse polygonized areas were observed as well - showing lower density of dislocations (Fig. 14). Presence of the polygonized areas in the cast steel after heat treatment can be caused by the difference in chemical composition of particular grains resulting from a dendritic micro segregation or from the lack of austenite homogeneity during heat treatment. Differences of chemical composition may cause local decrease in the temperature of recrystallization.

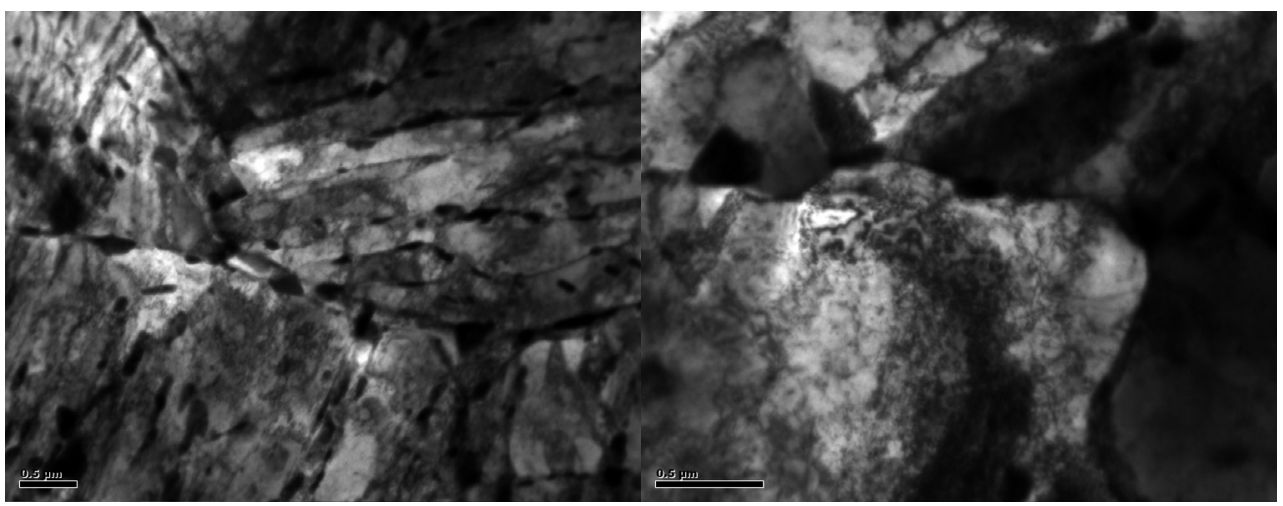

Figure 14. Microstructure of the L21HMF cast steel after heat treatment (bainitic hardening and hightemperature tempering)

Normalizing and tempering allowed obtaining tempered bainitic - ferritic structure with around $20 \%$ of ferrite in the $\mathrm{Cr}-\mathrm{Mo}-\mathrm{V}$ cast steel.

The observed microstructures after bainitic hardening and normalizing, apart from ferrite amount in the structure, differed in bainite morphology as well. After bainitic hardening only the "needle-shaped" form of bainite was observed, and it was morphologically similar to martensite, which indicates lower bainite presence in the structure (it can also be proved by the characteristic arrangement of carbides illustrated in Fig. 14). After normalization, however, the $\mathrm{Cr}-\mathrm{Mo}-\mathrm{V}$ cast steel microstructure showed the "feathery" bainite form, which indicates the presence of upper bainite. Apart from the "feathery" bainite also some single areas of „needle-shaped” bainite could be seen.

The identifications of precipitates performed by means of the extraction carbon replicas revealed in the investigated cast steel after heat treatment (in the tempered bainitic and bainitic - ferritic structure) the occurrence of the following carbide types: $M C, M_{3} C_{2} M_{7} C_{3}$ and $\mathrm{M}_{23} \mathrm{C}_{6}$.

The study of mechanical properties at room temperature has shown that the structure of high-temperature tempered bainite provides the combination of high strength properties and impact energy. Tensile strength and yield strength after tempering exceeded the minimum requirements considerably, and similarly, the impact energy was several times 
higher than the required minimum of 27J for the new castings (Table 5, Fig. 15). Tempering of L21HMF cast steel with bainitic structure at the temperatures which are 10 and $20{ }^{\circ} \mathrm{C}$ higher than the maximum tempering temperature recommended by the standard, i.e. at 720 and $730 \mathrm{oC}$, caused an increase in impact energy by 8 and 35\%, respectively, with the hardness decrease by $2 \div 5 \%$ in comparison with the tempering temperature of $710{ }^{\circ} \mathrm{C}$ (Fig. 15).

Therefore, it can be concluded that for the cast steels of bainitic microstructure it is possible to apply higher temperatures of tempering compared to the ones recommended by the standards, without concern that the strength properties can go down below the required minimum. Apart form obtaining high impact energy with the required strength properties maintained, it also allows to achieve the microstructure of higher thermodynamic stability, which can guarantee slower process of its degradation.

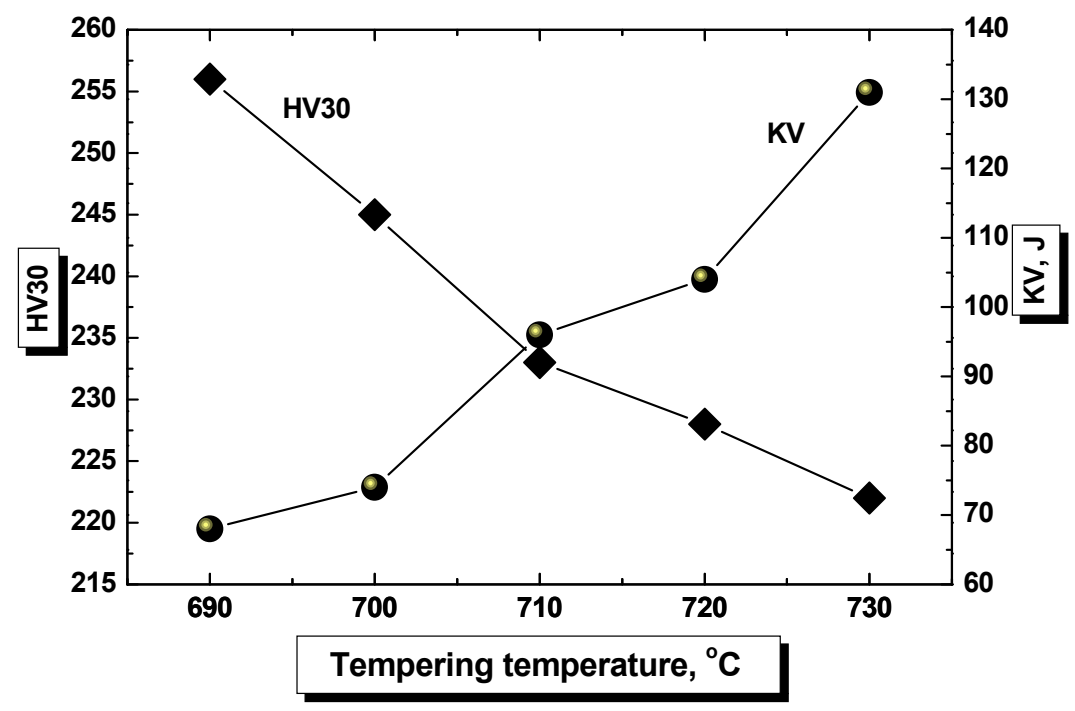

Figure 15. Influence of the tempering temperature on hardness and impact energy of the L21HMF cast steel with bainitic structure

The cast steel of tempered mixed (bainitic - ferritic) microstructure was characterized by the strength properties on a similar level as the cast steels with bainitic microstructure. However, the crack resistance of those cast steels was almost two times as low compared to that of cast steels with bainitic microstructure (Table 6).

High impact energy of the cast steel with the microstructure of tempered bainite is a consequence of large total amount of grain boundaries (boundaries of bainite packets) and high ductility of the tempered microstructure of lower bainite. Whilst, lower impact energy 
of the cast steel with mixed bainitic - ferritic structure results from the presence of ferrite in the microstructure, which favours the fissile cracking, and from the presence of upper bainite, characterized by greater brittleness than lower bainite.

Full annealing allows to obtain ferritic - pearlitic microstructure for the examined cast steel grade (Fig. 13d), with pearlite located mostly on ferrite grain boundaries. In pearlite the processes of fragmentation and spheroidization of carbides could be observed. The ferritic - pearlitic microstructure obtained as a result of repeated cooling from the austenitizing temperature was morphologically similar to the microstructure after longterm service.

\begin{tabular}{|c|c|c|c|c|c|c|}
\hline $\begin{array}{l}\text { Heat treatment } \\
\text { parameters }\end{array}$ & $\begin{array}{c}\mathrm{TS} \\
\mathrm{MPa}\end{array}$ & $\begin{array}{c}\mathrm{YS} \\
\mathrm{MPa}\end{array}$ & $\begin{array}{c}\text { El. } \\
\%\end{array}$ & $\begin{array}{c}\mathrm{KV} \\
\mathrm{J}\end{array}$ & HV30 & Microstructure \\
\hline after service & 545 & 305 & 26 & 10 & 156 & ferritic-pearlitic \\
\hline $\begin{array}{c}\text { bainitic hardening } \\
+ \\
720^{\circ} \mathrm{C} / 4 \mathrm{~h}\end{array}$ & 728 & 620 & 18 & 104 & 228 & bainitic \\
\hline $\begin{array}{c}\text { normalizing } \\
+ \\
720^{\circ} \mathrm{C} / 4 \mathrm{~h}\end{array}$ & 721 & 594 & 17 & 62 & 220 & bainitic-20\%ferritic \\
\hline $\begin{array}{c}\text { full annealing } \\
+ \\
720^{\circ} \mathrm{C} / 4 \mathrm{~h}\end{array}$ & 558 & 336 & 27 & 26 & 153 & ferritic- $20 \%$ pearlitic \\
\hline $\begin{array}{c}\text { full annealing } \\
+ \\
800^{\circ} \mathrm{C} / 4 \mathrm{~h}\end{array}$ & 552 & 316 & 31 & 42 & 162 & ferritic- $20 \%$ pearlitic \\
\hline $\begin{array}{c}\text { full annealing } \\
+ \\
820^{\circ} \mathrm{C} / 4 \mathrm{~h}\end{array}$ & 550 & 324 & 28 & 42 & 164 & ferritic- $20 \%$ pearlitic \\
\hline${ }^{*} \mathrm{PN}$ requirements & $\begin{array}{l}500 \\
\div \\
670\end{array}$ & $\begin{array}{c}\min . \\
320\end{array}$ & $\begin{array}{c}\min . \\
20\end{array}$ & $\begin{array}{c}\min . \\
27\end{array}$ & $\begin{array}{l}140^{* *} \\
\quad \div \\
197\end{array}$ & - \\
\hline
\end{tabular}

*- PN - 89/ H - 83157 ; ** - hardness according to Brinell

Table 5. Microstructure and properties of the L21HMF cast steel after heat treatment 


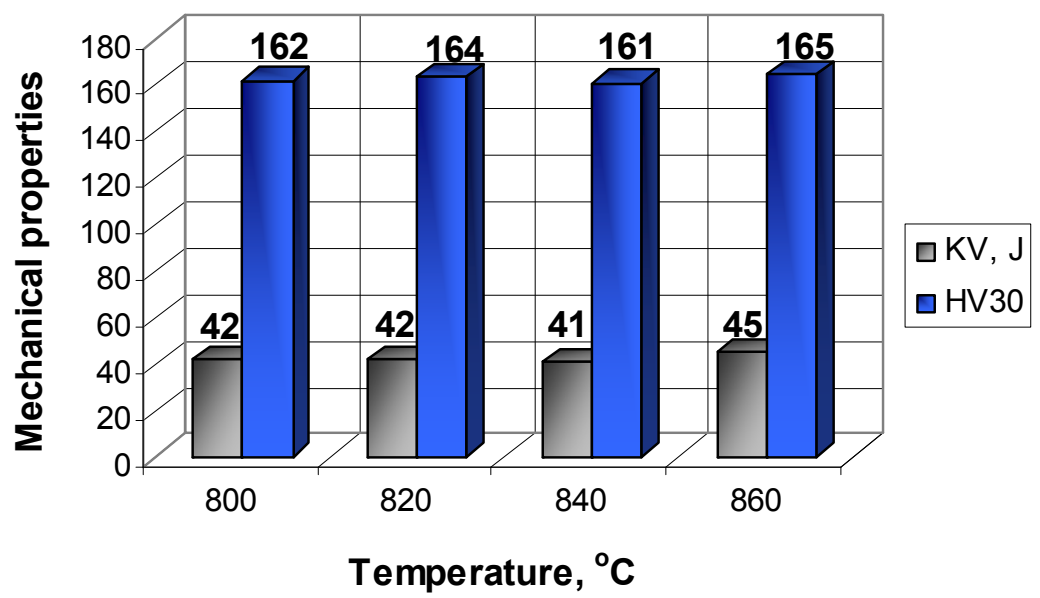

Figure 16. Change in the values of hardness and impact energy of the cast steel depending on the temperature of $(\alpha+\gamma)$ annealing

For the L21HMF cast steel of ferritic - pearlitic microstructure it is required to apply $(\alpha+\gamma)$ annealing (under annealing) instead of tempering which did not always provide the required impact energy. Applying under annealing causes: dissolution of carbides precipitated on grain boundaries during slow cooling from the temperature of austenitization, decrease of phosphorus segregation on ferrite grain boundaries and further reduction of austenite grain size. This allows to obtain the required strength properties and impact energy KV on the level $\sim 40 \mathrm{~J}$. The influence of $(\alpha+\gamma)$ annealing temperature on the value of impact energy and hardness is presented in Fig.16.

The performed heat treatment, apart from the changes in microstructure and properties of the examined cast steels, also caused a change in the mechanism of cracking (Fig. 17). In the cast steel of high-temperature tempered bainite structure, on the entire surface under the fracture, there was a transcrystalline ductile fracture initiated by fine-dispersion precipitates of carbides and sulfide inclusions (Fig. 17a). The characteristic feature of plastic cracking is its ability to absorb significant amounts of energy connected with plastic deformations preceding the decohesion. The cast steel of bainitic - ferritic structure was subject to decohesion through mixed mechanism. Directly under the notch, at a depth of about $1.0 \div$ $1.5 \mathrm{~mm}$, cracking proceeded in plastic manner through transcrystalline ductile mechanism. Below the area of plastic strain, fissile cracking could be observed, running through a transcrystalline fissile mechanism with micro fields of ductile character.

The cast steel with regenerated ferritic - pearlitic structure, obtained as a result of slow cooling and under annealing, was cracking through a mechanism similar to decohesion of the cast steel after service, i.e. transcrystalline fissile mechanism with micro fields of ductile character (Fig. 17b). 

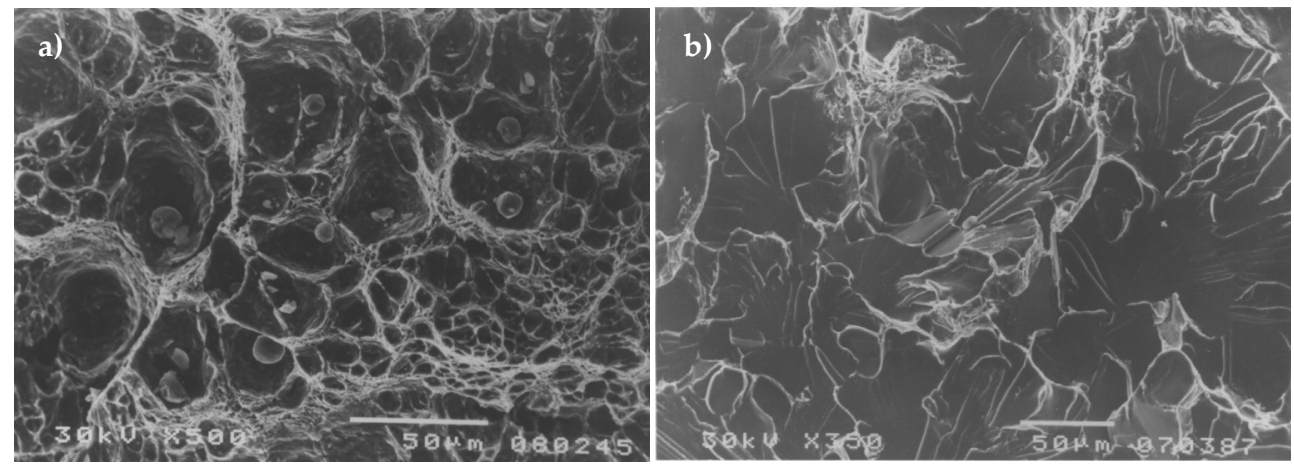

Figure 17. Cracking mechanism of cast steel: a) transcrystalline ductile for tempered bainitic microstructure; b) transcrystalline fissile for ferritic - pearlitic microstructure

\section{Summary}

The research performed on the L21HMF cast steel, taken from a steam turbine cylinder serviced for around 186000 hours at the temperature of $540{ }^{\circ} \mathrm{C}$, has revealed that long-term service contributed to: the processes of recovery and polygonization of ferrite grains, preferential precipitation of $\mathrm{M}_{23} \mathrm{C}_{6}$ carbides on grain boundaries and formation of ${ }_{1} \mathrm{H}-$ carbide" complexes near the boundary areas of ferrite grains. During long-term operation the strength properties were decreasing slowly - yet faster in the case of yield strength than tensile strength, and the impact energy decreased drastically below the required minimum level of 27J.

Changes in the microstructure and properties of the long-term serviced cast steel do not eliminate the possibilities of their further safe operation. Extending the safe operation time beyond the calculative time of 100000 hours (with the target up to $200 \div 250000$ hours) is possible thanks to regenerative heat treatment.

Performed research has proved that applying bainitic hardening instead of normalizing/full annealing, thus far applied in the castings, allows to achieve the best combination of high strength properties and very high impact energy. Moreover, the bainitic microstructure makes it possible to apply high temperatures of tempering, amounting to $710 \div 730{ }^{\circ} \mathrm{C}$. This allows increasing the stability of microstructure of long-term serviced cast steels without concern for reduction in the strength properties below the required minimum. High impact energy KV > 100J of the cast steel with high-tempered bainite structure guarantees that after long-term operation the impact energy will not drop below the minimum required level of 27J.

Applying normalizing for the castings allows to obtain bainitic - ferritic microstructure, which is characterized by similar strength properties as the cast steel with tempered bainitic microstructure, with the impact energy, however, being almost two times as low. What 
seems evident here, is the negative influence of ferrite in the microstructure on the impact strength.

The ferritic - pearlitic microstructure, obtained as a result of slow cooling of the castings from the austenitizing temperature (full annealing), allows to obtain the strength properties comparable to those after service and impact energy on the level of 40J. After the process of full annealing it is recommended to apply the $(\alpha+\gamma)$ annealing (under annealing) instead of the process of tempering, which makes it possible to obtain the required impact energy.

\section{Author details}

Grzegorz Golański

Institute of Materials Engineering, Czestochowa University of Technology, Poland

\section{References}

[1] Zieliński A., Dobrzański J., Krztoń H., Structural changes in low alloy cast steel $\mathrm{Cr}$ - Mo $-V$ after long time creep service, JAMME, 25, 2007, 33

[2] Stachura S., Changes of structure and mechanical properties in steels and cast steels utilised in increased temperatures, Energetyka, 2, 1999, 109

[3] Balyts'kyi O.I., Ripei I.V., Protsakh Kh. A., Degradation of the cast elements of steam turbines of thermal power plants made of 20KhMFL steel in the course of long - term operation, Materials Science, 41, 3, 2005, 423

[4] Dobosiewicz J., Influence of operating conditions on the changes in mechanical properties of steam turbine cylinders, Energetyka, 1992, 1, 27

[5] Stachura S., Kupczk J., Gucwa M., Optimization of structure and properties of $\mathrm{Cr}-\mathrm{Mo}$ and $\mathrm{Cr}$ - Mo - V cast steel intended for use at increased temperature, Foundry Review, 54, 5, 2004, 402

[6] Stachura S., Trzeszczyński J., The choice of the regenerative thermal treatment of the $\mathrm{Cr}-\mathrm{Mo}$ and $\mathrm{Cr}-\mathrm{Mo}-V$ cast steel, Inżynieria Materiałowa, 6, 1997, 227

[7] Lu Z., Faulkner R.G., Flewitt P. E. J., The role of irradiation - induced phosphorus segregation in the DBTT temperature in ferritic steel, Mater. Sc. Eng., A 437, 2006, 306

[8] Islam M. A.,. Knott J. F, Bowen P., Kinetics of phosphorus segregation and its effect on low temperature fracture behaviour in $2.25 \mathrm{Cr}-1 \mathrm{Mo}$ pressure vessel steel, Materials Sc. and Techn., 21, 1, 2005, 76

[9] Molinie E., Piques R., Pineau A., Behaviour of a 1Cr - 1Mo - 0.25V steel after long - term exposure - I. Charpy impact toughness and creep properties, Fatique Fract. Eng. Mater. Struct., 14, 5, 1991, 531

[10] Stachura S., Golański G., Metallographic and mechanical properties of steel and cast steel after long term service at elevated temperatures, Report BZ - $202-1 / 01$ unpublished researched

[11] Golański G., Stachura S., Kupczyk J., Kucharska - Gajda B., Heat treatment of cast steel using normalization and intercritical annealing, Arch. Foundry Eng., 7, 2007, 123 
[12] Komai N., Masuyama F., Igarashi M., 10 - year experience with $T 23(2.25 \mathrm{Cr}-1.6 \mathrm{~W})$ and T122 (12Cr-0.4Mo - 2W) in a power boiler, Transations of the ASME, 127, 2005, 190

[13] Trzeszczyński J., Grzesiczek E.,. Brunne W, Effectiveness of solutions extending operation time of long operated cast steel elements of steam turbines and steam pipelines, Energetyka, 3, 2006, 179

[14] Rehmus - Forc A., Change of structure after revitalization cylinders of a steam turbine, Inżynieria Materiałowa , 2006, 3, 265

[15] Golański G., Influence tempering temperature on mechanical properties of cast steels, Archives of Foundry Eng., 8, 4, 2008, 47

[16] Dobosiewicz J., Reasons for regenerating steam turbine cylinders, Energetyka, 1996, 11, 634

[17] Łukowski J., Modern installations for quenching with the application of aqueous polimer solutions, Przegląd Odlewnictwa, 51, 2001, 2, 57

[18] Bakalarski A., Nowarski A., Sus J., Wyszyński K., Theoretical investigation and experimental application of aqueous polymer solution for quenching products of low-alloy cast steel, Przegląd Odlewnictwa, 51, 2001, 2, 61

[19] Golański G., Stachura S., Gajda B., Kupczyk J., Influence of the cooling rate on structure and mechanical properties of L21HMF cast steel after regenerative heat treatment, Archives of Foundary, 6, 21, 2006, 143

[20] Zieliński A., Dobrzański J., Golański G., Estimation of residual life of L17HMF cast steel elements after long - term service, J. Achievements in Materials and Manufacturing Eng.., 34, 2, 2009, 137

[21] Golański G., Microstructure and mechanical properties of G17CrMoV5 - 10 cast steel after regenerative heat treatment, J. Pressure Vessel Techn., 132, 2010, 064503-1

[22] Golański G., Stachura S., Kupczyk J., Kucharska - Gajda B., Optimisation of regenerative heat treatment of G21CrMoV4 - 6 cast steel, Archives Mater. Sc. Eng., 28, 6, 2007, 341

[23] Murphy M.C., Branch G. D., The microstructure, creep and creep - rupture properties of $\mathrm{Cr}-$ Mo - V steam turbine castings, JISI, 1969, 1347

[24] Senior B. A., A critical review of precipitation behavior in $1 \mathrm{Cr}-\mathrm{Mo}-\mathrm{V}$ rotor steels, Mater. Sc. Eng. A, 1988, 103, 263

[25] Williams K. R., Wilshire B., Microstructural instability of $0.5 \mathrm{Cr}-0.5 \mathrm{Mo}-0.25 \mathrm{~V}$ creep resistant steel during service at elevated temperatures, Mater. Sci. Eng., 1981, 47, 151

[26] Danielsen H. K., Hald J., Behaviour of Z phase in 9 - 12 \% Cr steels, Energy, 1, 1, 2006, 49

[27] Golański G., Mechanical Properties of G17CrMoV5 - 10 Cast Steel after Regenerative Heat Treatment, Solid State Phenom. 147 - 149, 2009, 732

[28] Ryś J., Stereology of materials, FOTOBIT Publ., Cracow, 1995

[29] Taylor J.P., Blondeau R., The respective roles of the packet size and the lath width on toughness, Metall. Trans., 7A, 1976, 891

[30] H. Kotilainen, The micromechanisms of cleavage fracture and their relationship to fracture toughness in a bainitie Low Alloy Steel, VTT, Espoo, Finland, 1980 
[31] Bhadeshia H. K. D. H., Bainite in steels, $2^{\text {nd }}$ edition, The University Press Cambridge, Cambridge, UK, 2001

[32] PN - 89/ H - 83157 Cast steels for elevated temperature applications. Grades. 